Dept. of Anat., Kyoto Prefectural Med. College (Director: Prof. Dr. H. NODA).

\title{
Preliminary Test of Fixatives and Other Fluids Used in Autoradiographic Technics in Histology.
}

$\mathrm{P}^{32}$ の溶出率から見た各種固定法の autoradiography への 適否について。

\author{
Yutaka SANO, Mitoko KAWAMOTO, Seiichirō TAKAHASHI \\ 佐 野 豊, 川本溪子, 高橋誠一郎. \\ (Received January 15, 1957.)
}

Recently, investigations are being carried out in histology in applying radioactive isotopes, especially autoradiography. Besides making investigations with the freeze-drying method on extremely small blocks of tissue, the application of autoradiography has come to be necessary in routine histological laboratory works. LEBLOND, STEVENS and BOGORCH (1948), HOLT, COWING and WARREN (1949), HOLT and WARREN (1951) and BLANK, MC CARTHY and DE LAMATER (1951) etc. have given too much emphasis on the freezing drying method and seem to lack interest in appreciating some of the more common methods of application. In reference to the fundamental studies concerning the influence of fixation with common fixatives and dehydrating process on radioactivity, only few investigations have been made, some of which are the investigations of KAMINSKI (1955), LAMERTON and HARRIS (1951) and that of KOYAMA and NAGAYAMA (1955). In their reports, differences of influence on radioactivity caused by different fixatives are given. However, as to the differences in different tissue materials fixed in the same fixative, no description is made. By means of applying $\mathrm{P}^{32}$, investigation was carried out here in an attempt to solve some points of the problem in question.

\section{Material and Method.}

Four female rats weighing $110 \mathrm{~g}$ each were used. Two rats were used in each experiment and experiments were carried out twice. Each animal was injected intraperitonealy with $0.5 \mathrm{mc}$ of $\mathrm{P}^{32}\left(\mathrm{Na}_{2} \mathrm{HPO}_{4}\right)$, and 20 hours after injection, small pieces from the animal's kidney, liver, cardiac muscle, brain, and quadriceps extensor muscle were taken out under chloroform narcosis. Each piece of tissue weighed approximately $40 \mathrm{mg}$. Loss of $\mathrm{P}^{32}$ in these tissues was investigated under different fixatives and processes such as given in table 1 . Standard radioactivity of each tissue was deter- 
mined beforehand by counting $\mathrm{P}^{32}$ radioactivity in $40 \%$ solution of $\mathrm{KOH}$ digesting the corresponding piece of tissue. In the experimentals, the $\mathbf{P}^{32}$

Table 1. Time (hr) spent in various fixatives and in subsequent fluids.

\begin{tabular}{|c|c|c|c|c|c|c|c|c|c|c|c|}
\hline & \multirow{2}{*}{ Fixative } & \multirow{2}{*}{$\begin{array}{l}\text { Wash- } \\
\text { ing }\end{array}$} & \multicolumn{6}{|c|}{$\begin{array}{l}\text { Dehydration (through ascending } \\
\text { grades of alcohol) }\end{array}$} & \multirow{2}{*}{$\left|\begin{array}{c}\text { Clear- } \\
\text { ing } \\
(x y l o l)\end{array}\right|$} & \multirow{2}{*}{$\begin{array}{c}\text { Embed- } \\
\text { ding } \\
\text { (paraffin) }\end{array}$} & \multirow{2}{*}{ Total } \\
\hline & & & $70 \%$ & $80 \%$ & $90 \%$ & $95 \%$ & $98 \%$ & abs. alc. & & & \\
\hline $\begin{array}{l}\text { absolute } \\
\text { alcohol }\end{array}$ & $\begin{array}{c}3 \\
\text { (three } \\
\text { changes })\end{array}$ & - & - & - & - & - & - & - & 0.5 & 2 & 5.5 \\
\hline $\begin{array}{l}\text { CARNOY's } \\
\text { fluid }\end{array}$ & 2 & - & - & - & - & - & - & $\begin{array}{c}3 \\
\text { (four } \\
\text { changes) }\end{array}$ & 0.5 & 2 & 7.5 \\
\hline $\begin{array}{c}\text { formalin- } \\
\text { alcohol } \\
\text { mixture }\end{array}$ & 5 & - & 4 & 14 & 5 & 5 & - & 14 & 0.5 & 2 & 49.5 \\
\hline $\begin{array}{l}\text { BOUIN's } \\
\text { fluid }\end{array}$ & 5 & - & 4 & 14 & 5 & 5 & - & 14 & 0.5 & 2 & 49.5 \\
\hline $\begin{array}{l}\text { SCHAU- } \\
\text { DINN's } \\
\text { fluid }\end{array}$ & 5 & - & - & - & $\begin{array}{c}18 \\
\text { (four } \\
\text { changes) }\end{array}$ & 3 & 2 & 3 & 0.5 & 2 & 33.5 \\
\hline $\begin{array}{c}\text { 'susa' } \\
\text { (HEIDEN- } \\
\text { HAIN's) }\end{array}$ & 5 & - & - & - & $\begin{array}{c}18 \\
\text { (four } \\
\text { changes) }\end{array}$ & 3 & 2 & 3 & 0.5 & 2 & 33.5 \\
\hline $\begin{array}{l}\text { ORTH's } \\
\text { fluid }\end{array}$ & 5 & 5 & 13 & 5 & 5 & 14 & 2 & 3 & 0.5 & 2 & 54.5 \\
\hline
\end{tabular}

Table 2. Loss of radioactive phosphorus $\left(\mathbf{P}^{32}\right)$ from rat brain, liver, kidney, striated muscle and cardiac muscle in various fixatives and in subsequent fluids (\%).

\begin{tabular}{|c|c|c|c|c|c|c|}
\hline & Fixative & $\begin{array}{l}\text { Loss in } \\
\text { fixative }\end{array}$ & $\begin{array}{c}\text { Loss in } \\
\text { water }\end{array}$ & $\begin{array}{l}\text { Loss in } \\
\text { alcohol }\end{array}$ & $\begin{array}{c}\text { Loss in } \\
\text { xylol }\end{array}$ & $\begin{array}{l}\text { Total loss } \\
\text { in proces- }\end{array}$ \\
\hline & absolute alcohol & $\begin{array}{l}20.1 \\
23.5\end{array}$ & - & - & $\begin{array}{l}3.3 \\
6.9\end{array}$ & $\begin{array}{l}23.4 \\
30.4\end{array}$ \\
\hline & CARNOY's fiuid & $\begin{array}{l}34.8 \\
36.8\end{array}$ & - & $\begin{array}{l}1.1 \\
3.9\end{array}$ & $\begin{array}{l}0 \\
0\end{array}$ & $\begin{array}{l}35.9 \\
40.7\end{array}$ \\
\hline & formalin-alcohol & $\begin{array}{l}19.3 \\
24.8\end{array}$ & - & $\begin{array}{l}22.6 \\
25.3\end{array}$ & $\begin{array}{l}6.7 \\
4.0\end{array}$ & $\begin{array}{l}48.6 \\
54.1\end{array}$ \\
\hline 茜 & BOUIN's fluid & $\begin{array}{l}36.5 \\
34.7\end{array}$ & - & $\begin{array}{l}20.8 \\
25.0\end{array}$ & $\begin{array}{l}1.0 \\
0.5\end{array}$ & $\begin{array}{l}58.3 \\
60.2\end{array}$ \\
\hline & SCHAUDINN's fluid & $\begin{array}{l}51.4 \\
52.2\end{array}$ & - & $\begin{array}{l}27.4 \\
28.7\end{array}$ & $\begin{array}{r}2.1 \\
0\end{array}$ & $\begin{array}{l}80.9 \\
80.9\end{array}$ \\
\hline & susa (HEIDENHAIN's) & $\begin{array}{l}63.6 \\
70.7\end{array}$ & - & $\begin{array}{l}28.7 \\
21.5\end{array}$ & $\begin{array}{r}0 \\
4.4\end{array}$ & $\begin{array}{l}92.3 \\
96.6\end{array}$ \\
\hline & ORTH's fluid & $\begin{array}{l}34.3 \\
34.1\end{array}$ & $\begin{array}{l}12.2 \\
14.5\end{array}$ & $\begin{array}{l}13.0 \\
15.1\end{array}$ & $\begin{array}{l}0 \\
0\end{array}$ & $\begin{array}{l}59.5 \\
63.7\end{array}$ \\
\hline
\end{tabular}




\begin{tabular}{|c|c|c|c|c|c|c|}
\hline \multirow{7}{*}{$\stackrel{8}{D}$} & absolute alcohol & $\begin{array}{l}26.5 \\
19.9\end{array}$ & - & - & $\begin{array}{r}0.5 \\
0\end{array}$ & $\begin{array}{l}27.0 \\
22.5\end{array}$ \\
\hline & CARNOY's fluid & $\begin{array}{l}32.8 \\
28.4\end{array}$ & - & $\begin{array}{l}2.4 \\
1.8\end{array}$ & $\begin{array}{r}0.1 \\
0\end{array}$ & $\begin{array}{l}35.3 \\
30.2\end{array}$ \\
\hline & formalin-alcohol & $\begin{array}{l}28.2 \\
28.0\end{array}$ & - & $\begin{array}{l}31.8 \\
26.3\end{array}$ & $\begin{array}{r}0.3 \\
0\end{array}$ & $\begin{array}{l}60.3 \\
54.3\end{array}$ \\
\hline & BOUIN's fluid & $\begin{array}{l}23.9 \\
27.4\end{array}$ & - & $\begin{array}{l}49.6 \\
36.2\end{array}$ & $\begin{array}{l}0 \\
0\end{array}$ & $\begin{array}{l}73.5 \\
63.6\end{array}$ \\
\hline & SCHAUDINN's fluid & $\begin{array}{l}37.4 \\
35.5\end{array}$ & - & $\begin{array}{l}37.0 \\
40.5\end{array}$ & $\begin{array}{l}0 \\
0\end{array}$ & $\begin{array}{l}74.4 \\
76.0\end{array}$ \\
\hline & susa (HEIDENHAIN's) & $\begin{array}{l}22.2 \\
27.2\end{array}$ & - & $\begin{array}{l}49.8 \\
45.5\end{array}$ & $\begin{array}{l}0 \\
0\end{array}$ & $\begin{array}{l}72.0 \\
72.7\end{array}$ \\
\hline & ORTH's fluid & $\begin{array}{l}12.8 \\
14.5\end{array}$ & $\begin{array}{r}8.3 \\
12.0\end{array}$ & $\begin{array}{l}38.0 \\
33.6\end{array}$ & $\begin{array}{l}0 \\
0\end{array}$ & $\begin{array}{l}59.1 \\
60.1\end{array}$ \\
\hline \multirow{7}{*}{$\frac{\vec{d}}{\vec{g}}$} & absolute alcohol & $\begin{array}{l}25.1 \\
29.2\end{array}$ & - & - & $\begin{array}{l}2.1 \\
0.2\end{array}$ & $\begin{array}{l}27.2 \\
29.4\end{array}$ \\
\hline & CANORY's fluid & $\begin{array}{l}30.3 \\
28.4\end{array}$ & - & $\begin{array}{l}1.2 \\
3.9\end{array}$ & $\begin{array}{l}0 \\
0\end{array}$ & $\begin{array}{l}31.5 \\
32.3\end{array}$ \\
\hline & formalin-alcohol & $\begin{array}{l}45.2 \\
35.2\end{array}$ & - & $\begin{array}{l}21.4 \\
34.3\end{array}$ & $\begin{array}{r}0.6 \\
0\end{array}$ & $\begin{array}{l}66.2 \\
69.6\end{array}$ \\
\hline & BOUIN's fluid & $\begin{array}{l}30.3 \\
29.2\end{array}$ & - & $\begin{array}{l}39.4 \\
39.1\end{array}$ & $\begin{array}{l}0 \\
0\end{array}$ & $\begin{array}{l}69.7 \\
68.3\end{array}$ \\
\hline & SCHAUDINN's fluid & $\begin{array}{l}48.4 \\
42.6\end{array}$ & - & $\begin{array}{l}28.1 \\
31.8\end{array}$ & $\begin{array}{l}0 \\
0\end{array}$ & $\begin{array}{l}76.5 \\
74.4\end{array}$ \\
\hline & susa (HEIDENHAIN's) & $\begin{array}{l}34.6 \\
30.7\end{array}$ & - & $\begin{array}{l}41.6 \\
42.9\end{array}$ & $\begin{array}{l}0 \\
0\end{array}$ & $\begin{array}{l}76.2 \\
73.6\end{array}$ \\
\hline & ORTH's fluid & $\begin{array}{l}14.5 \\
16.6\end{array}$ & $\begin{array}{l}6.7 \\
5.1\end{array}$ & $\begin{array}{l}30.0 \\
20.7\end{array}$ & $\begin{array}{l}0 \\
0\end{array}$ & $\begin{array}{l}51.2 \\
42.4\end{array}$ \\
\hline \multirow{7}{*}{ 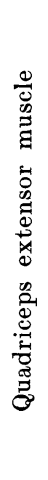 } & absolute alcohol & $\begin{array}{l}4.9 \\
6.6\end{array}$ & - & - & $\begin{array}{l}0.1 \\
0.3\end{array}$ & $\begin{array}{l}5.0 \\
6.9\end{array}$ \\
\hline & CARNOY's fluid & $\begin{array}{r}12.2 \\
9.1\end{array}$ & - & $\begin{array}{l}0.5 \\
2.3\end{array}$ & $\begin{array}{l}0 \\
0\end{array}$ & $\begin{array}{l}12.7 \\
11.4\end{array}$ \\
\hline & formalin-alcohol & $\begin{array}{l}37.9 \\
38.4\end{array}$ & - & $\begin{array}{l}16.9 \\
11.7\end{array}$ & $\begin{array}{l}0 \\
0\end{array}$ & $\begin{array}{l}54.8 \\
50.1\end{array}$ \\
\hline & BOUIN's fluid & $\begin{array}{l}48.4 \\
50.4\end{array}$ & - & $\begin{array}{l}9.5 \\
7.7\end{array}$ & $\begin{array}{l}0 \\
0\end{array}$ & $\begin{array}{l}57.9 \\
58.2\end{array}$ \\
\hline & SCHAUDINN's fluid & $\begin{array}{l}79.9 \\
81.1\end{array}$ & - & $\begin{array}{l}3.8 \\
5.1\end{array}$ & $\begin{array}{l}0 \\
0\end{array}$ & $\begin{array}{l}83.7 \\
86.2\end{array}$ \\
\hline & susa (HEIDENHAIN's) & $\begin{array}{l}68.0 \\
66.7\end{array}$ & - & $\begin{array}{l}3.9 \\
7.9\end{array}$ & $\begin{array}{l}0 \\
0\end{array}$ & $\begin{array}{l}71.9 \\
74.6\end{array}$ \\
\hline & ORTH's fluid & $\begin{array}{l}56.3 \\
56.8\end{array}$ & $\begin{array}{l}4.0 \\
4.8\end{array}$ & $\begin{array}{l}3.5 \\
4.3\end{array}$ & $\begin{array}{l}0 \\
0\end{array}$ & $\begin{array}{l}63.8 \\
66.9\end{array}$ \\
\hline \multirow{3}{*}{ 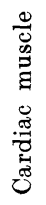 } & absolute alcohol & $\begin{array}{l}19.2 \\
18.9\end{array}$ & - & - & $\begin{array}{l}0.9 \\
0.2\end{array}$ & $\begin{array}{l}20.1 \\
19.1\end{array}$ \\
\hline & CARNOY's fluid & $\begin{array}{l}23.2 \\
22.4\end{array}$ & - & $\begin{array}{l}0.9 \\
0.4\end{array}$ & $\begin{array}{l}0 \\
0\end{array}$ & $\begin{array}{l}24.1 \\
22.8\end{array}$ \\
\hline & formalin-alcohol & $\begin{array}{l}22.4 \\
22.9\end{array}$ & - & $\begin{array}{l}18.4 \\
15.0\end{array}$ & $\begin{array}{l}1.9 \\
3.9\end{array}$ & $\begin{array}{l}42.7 \\
41.8\end{array}$ \\
\hline
\end{tabular}




\begin{tabular}{|c|c|c|c|c|c|c|}
\hline & BOUIN's fluid & $\begin{array}{l}73.5 \\
71.7\end{array}$ & - & $\begin{array}{l}19.6 \\
20.2\end{array}$ & $\begin{array}{l}0.3 \\
0.2\end{array}$ & $\begin{array}{l}93.4 \\
92.1\end{array}$ \\
\hline $\overrightarrow{\overline{0}}$ & SCHAUDINN's fluid & $\begin{array}{l}60.8 \\
60.3\end{array}$ & $=$ & $\begin{array}{l}12.8 \\
14.9\end{array}$ & $\begin{array}{r}0.6 \\
0\end{array}$ & $\begin{array}{l}74.2 \\
75.2\end{array}$ \\
\hline & susa (HEIDENHAIN's) & $\begin{array}{l}69.5 \\
63.6\end{array}$ & 二 & $\begin{array}{l}19.1 \\
15.7\end{array}$ & $\begin{array}{r}0 \\
0.7\end{array}$ & $\begin{array}{l}88.6 \\
80.0\end{array}$ \\
\hline & ORTH's fluid & $\begin{array}{l}40.2 \\
37.2\end{array}$ & $\begin{array}{l}8.0 \\
1.3\end{array}$ & $\begin{array}{l}14.3 \\
10.4\end{array}$ & $\begin{array}{r}0.6 \\
0\end{array}$ & $\begin{array}{l}63.1 \\
48.9\end{array}$ \\
\hline
\end{tabular}

count was determined in each respective fixative and other processing liquid, in which tissue pieces had been placed. Counts were made with the dip counter (TEN, GM-413). Loss of $\mathrm{P}^{32}$ was given here in percentage lost. These values were obtained by setting the radioactive count (cpm/ tissue weight) in a standard solution as $100 \%$. As the fixation time and subsquent process are different with each fixative, its unification is impossible, and in order to prevent excessive loss of $\mathrm{P}^{32}$ the tissues were embedded as quickly as possible according to the general method of hitological preparation. Time standards used for investigation are given in the following table. Units given are in hours.

\section{Results and Consideration.}

The percentage loss of $\mathrm{P}^{32}$ of the tissues in fixatives, water, alcohol and xylol is given in table 2. Except for the results obtained with cardiac muscle fixed in ORTH's fluid, error of the data of total loss in experiments carried out twice was found to be less than $10 \%$. These results led to the assumption that no great difference arose owing to different species of animals or to the time spent for fixation of different tissues. Each piece of tissue weighed with the torsion balance was approximately $40 \mathrm{mg}$. Taking the errors of the weighing and the errors of the counting into consideration, errors less than $10 \%$ could be allowed. Consequently, considerable reliance might be laid in speculating as follows from the data given above. Neglecting the fact that the procedure after the fixation was different with each of the fixatives, the time spent after fixation in embedding was in the following order: alcohol, CARNOY's fluid, SCHAU. DINN's fluid, 'susa', formalin-alcohol mixture, BOUIN's fluid and ORTH's fluid. The loss of $\mathrm{P}^{32}$ was found to be less in every tissue fixed with ORTH's fluid than in those with SCHAUDINN or 'susa' fixation. Fixation with alcohol or CARNOY's fluid, both requiring little time in the procedure, was found to be much better than any other fixation. Here, the ability of the fixative fluid itself was considered to have more significance than the time factor. Thus, unless the time was too long, the time factor was of small importance. With the alcohol fixation, in which no water washing or dehydration was necessary, $\mathrm{P}^{32}$ was always found to be lost during the process of clearing with xylol. However, in other 
fixation methods much of the loss was found to take place before dehydration, and the loss in xylol was found to be $6.9 \%$ at the most throughout all experiments. Thus the loss of $\mathrm{P}^{32}$ in xylol might be neglected.

In samples of brain, quadriceps muscle and cardiac muscle, the loss of $\mathrm{P}^{32}$ was found to be greatest during the fixation process, and except for samples fixed with absolute alcohol or CARNOY's fluid, the loss in samples of liver and kidney was found to be great during the dehydration process.

Radioactive phosphate ions are generally believed to exchange rapidly with the non-radioactive phosphate within the tissues or cells and incorporate into phospholipids and nucleic acids (LEBLOND, STEVENS and BOGOROCH 1948), and all $\mathrm{P}^{32}$ introduced into the tissue is known normally to be incorporated into newly-formed nucleic acids. Therefore, in the study of DNA, the fixation method causing large loss of $\mathrm{P}^{32}$ is not considered to be appropriate. In respect to this speculation, absolute alcohol and CARNOY's fixative, employed hitherto for the purpose of fixing the nucleus, may be considered to be excellent microanatomical fixatives. As stated by KAMINSKI (1955), the loss of $\mathrm{P}^{32}$ in each organ was found to be $60-70 \%$ and in cardiac muscle more than $90 \%$ in processing with BOUIN's fluid, a method widely employed for the purpose of nucleus fixation. This reveals the inadequacy of employing BOUIN's fluid in fixation of the nucleus.

As both SCHAUDINN's fluid and 'susa' contain sublimate, unless samples be treated with iodine in addition to the above process, black precipitates may lead to the misunderstanding of radioautography. In considering this fact and a large loss of $\mathbf{P}^{32}$ in them, employment of these solutions for fixation of any tissue is believed to be not suitable in the case of radioautography. But, as absolute alcohol and CARNOY's fluid are very poor cytoplasmic fixatives, these solutions will not always be the choice of a fixative. Therefore, in this case, formalin-alcohol mixture or ORTH's fluid will be appropriate. Concerning studies with tissues of the liver, difference in results is observed between those of KAMINSKI and ours. This difference seems to be due to difference in the time factor. The time in KAMINSKI's investigation after injection of $\mathrm{P}^{32}$ is shorter than that in our studies. Furthermore, as no reference is given in his study as to the time up to the embedding of the tissue, the comparison of his results with ours is impossible.

\section{Conculsion.}

Employing the brain, liver, kidney, quadriceps muscle and cardiac muscle of rat, an investigation was carried out concerning the loss of $\mathrm{P}^{32}$ $\left(\mathrm{Na}_{2} \mathrm{HPO}_{4}\right)$ from the tissue under condition of various fixatives and pro- 
cesses up to embedding. The loss was found to be smallest in any of the tissues when fixed with absolute alcohol or CARNOY's fluid. The loss was found to be $60-90 \%$ in all tissues when fixed with BOUIN, SCHAU. DINN or 'susa'. As $\mathrm{P}^{32}$ is incorporated into the intracellular nucleic acid, absolute alcohol is believed to be the most appropriate fixative for fixation of the nucleus. In investigating the cytoplasm or the distribution of $\mathbf{P}^{32}$, formalin-alcohol mixture or ORTH's fluid is believed to be the most appropriate fixative.

\section{内 容 自 抄.}

ラッテの腹腔内飞 $\mathrm{P}^{32}\left(\mathrm{Na}_{2} \mathrm{HPO}_{4}\right) \quad 0.5 \mathrm{mc}$ を注射し，20時間後飞腎，肝， 心, 脳及び大腿四頭筋を摘出, 約 $40 \mathrm{mg}$ の小片とし, これらに含まれて いた $\mathbf{P}^{32}$ の, 固定一包埋操作の間に失われる量を, 表に示した 7 種の術式

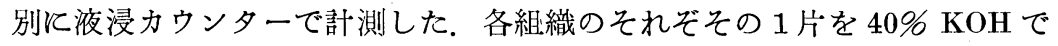
溶解したもの〉カウント数を基準とし，使用後の各被検液のカウント数を これと対する 100 分率で表わし， $\mathrm{P}^{32}$ の溶出率とする.

Orth 固定では何れの組織でも Schaudinn 及び susa 固定のものに比し て P 32 の溶出が少く，また包埋までの時間の最も短い alcohol 及び Carony は常飞他の固定液よりも良好であるが，それは時間が短いためよりる寧ろ 固定液自身の能力に帰せられる. 水洗，脱水を要しない alcohol を用いた 場合は常に xylol 中に括ける $\mathbf{P}^{32}$ の溶出が認められるが，その率は最高 $6.9 \%$ を超えない程度である. 脳, 大腿四頭筋，心筋では固定液中への溶 出が多く，肝，腎では，absolute alcohol とCarnoy を用いた場合を除き， 脱水中の溶出が多い.

細胞組織内に入った放射性 P は非放射性 P と交代しつ〉燐脂質や核酸飞 結合するのであるから， $\mathrm{P}^{32}$ の溶出率の高い固定法は，特に DNA を検索 するためとは，不適当であり，その意味で從来細胞核の固定液として用い られている absolute alcohol や Carnoy は良好な固定液であり，Bouin は 核には不適当な固定液である。しかし absolute alcohol や Carnoy は細胞 質の固定には適しないから，そのためには formalin - alcohol 混液又は Orth 液を使用すべきである，何れの組織を用いても溶出量の高い Schaudinn 液や susaは，これらが昇承を含んでいるために，沃素処理を行わな ければ黒色の沈澱を生じ，写真判定上の誤りを来たすことと相俟って，radioautography を目的する場合には甚だ不適当な固定液である. 


\section{References.}

Blank, H., P. L. McCarthy a. E. D. De Lamater: Stain Techn. 26 (1951). P. 193. - Holt, M. W., R. F. Cowing a. S. Warren : Science 110 (1949). P. 328. - Holt, M. W. a. S. Warren: Proc. Soc. exp. Biol. a. Med. 76 (1951). P. 4. - Kaminski, E. J.: Stain Techn. 30 (1955). P. 139 . - Koyama, Ts. a. Sh. Nagayama : Arch. hist. jap. 8 (1955). P. 139. - Lamerton, L. F. a. E. B. Harris: Brit. Med. J. 2 (1951). P. 932 . Leblond. C. P., C. E. Stevens a. R. Bogorch : Science 108 (1948). P. 531. 